Michael J. Arnold, MD; Dustin K. Smith, DO Uniformed Services University of the Health Sciences, Bethesda, MD (Dr. Arnold); Naval Hospital Jacksonville, FL (Dr. Smith)

- michael.arnold@usuhs. edu

The authors reported no potentia conflict of interest relevant to this article.

The views expressed in this article are those of the authors and do not necessarily reflect the official policy or position of the Department of the Navy, Uniformed Services University of the Health Sciences,

Department of Defense, or the uS government.

doi: 10.12788/jfp.0084

\title{
Primary prevention of VTE spans a spectrum
}

\author{
High mortality from VTE makes primary prevention \\ appealing. Guidelines and assessment tools offer a \\ variety of patient-specific strategies and agents.
}

\section{PRACTICE RECOMMENDATIONS \\ $\mathrm{V}$}

$>$ Consider the mild reduction in the risk of venous thromboembolism (VTE) provided by statins when contemplating their use for cardiovascular disease prevention. B

> Avoid testing for thrombophilia to determine the risk of VTE, except in pregnant patients who meet criteria for antiphospholipid syndrome or have a family history of VTE. B

> Recommend an intrauterine device or progestin-only pill for contraception if the patient's risk of VTE is high. B)

> Stratify hospitalized medical and nonorthopedic surgical patients by risk score to determine the need for VTE prophylaxis. B

Strength of recommendation (SOR)

A Good-quality patient-oriented evidence

B Inconsistent or limited-quality patient-oriented evidence

C Consensus, usual practice, opinion, disease-oriented evidence, case series enous thromboembolism (VTE) is a common and dangerous disease, affecting $0.1 \%-0.2 \%$ of the population annually - a rate that might be underreported. ${ }^{1}$ VTE is a collective term for venous blood clots, including (1) deep vein thrombosis (DVT) of peripheral veins and (2) pulmonary embolism, which occurs after a clot travels through the heart and becomes lodged in the pulmonary vasculature. Twothirds of VTE cases present clinically as DVT²; most mortality from VTE disease is caused by the $20 \%$ of cases of pulmonary embolism that present as sudden death. ${ }^{1}$

VTE is comparable to myocardial infarction (MI) in incidence and severity. In 2008, 208 of every 100,000 people had an MI, with a 30-day mortality of $16 / 100,000^{3}$; VTE disease has an annual incidence of 161 of every 100,000 people and a 28-day mortality of $18 / 100,000 .{ }^{4}$ Although the incidence and severity of MI are steadily decreasing, the rate of VTE appears constant. ${ }^{3,5}$ The high mortality of VTE suggests that primary prevention, which we discuss in this article, is valuable (see "Key points: Primary prevention of venous thromboembolism," page 388).

\section{Risk factors}

Virchow's triad of venous stasis, vascular injury, and hypercoagulability describes predisposing factors for VTE. ${ }^{6}$ Although venous valves promote blood flow, they produce isolated low-flow areas adjacent to valves that become concentrated and locally hypoxic, increasing the risk of clotting. ${ }^{7}$ The great majority of DVTs ( $\geq 96 \%$ ) occur in the lower extremity, ${ }^{8}$ starting in the calf; there, $75 \%$ of cases resolve spontaneously before they extend into the deep veins of the proximal leg. ${ }^{7}$ One-half of DVTs that do move into the proximal leg eventually embolize. ${ }^{7}$

Major risk factors for VTE comprise inherited conditions, medical history, medical therapeutics, and behaviors (TABLE 1) ${ }^{9-11}$ Unlike the preventive management of coronary artery disease (CAD), there is no simple, generalized prevention 
TABLE 1

Venous thromboembolism risk factors ${ }^{9-11}$

\begin{tabular}{|c|c|c|c|c|c|}
\hline Inherited conditions & RR & Intrinsic conditions & RR & Treatments and behavioral variables & $\mathrm{RR}$ \\
\hline $\begin{array}{l}\text { Factor V Leiden } \\
\text { - Homozygous } \\
\text { - Heterozygous }\end{array}$ & $\begin{array}{l}50 \\
5\end{array}$ & $\begin{array}{l}\text { History of venous } \\
\text { thromboembolism }\end{array}$ & 50 & Major surgery or trauma & $5-200$ \\
\hline Antithrombin III deficiency & 25 & $\begin{array}{l}\text { Age } \\
\text { - } 50-70 y \\
\text { - }>70 y\end{array}$ & $\begin{array}{l}5 \\
10\end{array}$ & $\begin{array}{l}\text { Estrogen } \\
\text { - Oral contraception } \\
\text { - Tamoxifen } \\
\text { - Hormone replacement therapy }\end{array}$ & $\begin{array}{l}5 \\
5 \\
2\end{array}$ \\
\hline Dysfibroginenemia & 18 & $\begin{array}{l}\text { Antiphospholipid } \\
\text { antibodies } \\
\text { - Lupus anticoagulant } \\
\text { - Anticardiolipin }\end{array}$ & $\begin{array}{l}10 \\
2\end{array}$ & Medical hospitalization & 5 \\
\hline Protein $\mathrm{C}$ or $\mathrm{S}$ deficiency & 10 & Pregnancy & 7 & Long-haul (> $4 \mathrm{~h}$ ) travel & 3 \\
\hline Hyperhomocysteinemia & 3 & Cancer & 6 & Smoking & $2-3$ \\
\hline Prothrombin mutation & 2.5 & Obesity & $1-3$ & & \\
\hline & & Hypertension & 2 & & \\
\hline & & Diabetes & 2 & & \\
\hline & & Hyperlipidemia & $1-2$ & & \\
\hline
\end{tabular}

$R R$, relative risk.

algorithm to address VTE risk factors.

I Risk factors for VTE and CAD over-

lap. Risk factors for atherosclerosisobesity, diabetes, smoking, hypertension, hyperlipidemia-also increase the risk of VTE (TABLE 1) ${ }^{9-11}$ The association between risk factors for VTE and atherosclerosis is demonstrated by a doubling of the risk of MI and stroke in the year following VTE. ${ }^{11}$ Lifestyle changes are expected to reduce the risk of VTE, as they do for acute CAD, but studies are lacking to confirm this connection. There is no prospective evidence showing that weight loss or control of diabetes or hypertension reduces the risk of VTE. ${ }^{12}$ Smoking cessation does appear to reduce risk: Former smokers have the same VTE risk as never-smokers. ${ }^{13}$

\section{Thrombophilia testing:}

\section{Not generally useful}

Inherited and acquired thrombophilic conditions define a group of disorders in which the risk of VTE is increased. Although thrombophilia testing was once considered for primary and secondary prevention of VTE, such testing is rarely used now because proof of benefit is lacking: A large case-control study showed that thrombophilia testing did not predict recurrence after a first VTE. ${ }^{14}$ Guidelines of the American College of Chest Physicians (ACCP) do not address thrombophilia, and the American Society of Hematology recommends against thrombophilia testing after a provoked VTE. ${ }^{15,16}$

Primary prophylaxis of patients with a family history of VTE and inherited thrombophilia is controversial. Patients with both a family history of VTE and demonstrated thrombophilia do have double the average incidence of VTE, but this increased risk does not offset the significant bleeding risk associated with anticoagulation. ${ }^{17}$ Recommendations for thrombophilia testing are limited to certain situations in pregnancy, discussed in a bit. $16,18,19$

\section{Primary prevention of VTE in the clinic}

There is no single, overarching preventive strategy for VTE in an ambulatory patient (although statins, discussed in a moment, offer 


\section{Key points: Primary prevention of venous thromboembolism}

- Primary prevention of venous thromboembolism (VTE), a disease with mortality similar to myocardial infarction, should be an important consideration in at-risk patients.

- Although statins reduce the risk of VTE, their use is justified only if they are also required for prevention of cardiovascular disease.

- The risk of travel-related VTE can be reduced by wearing compression stockings.

- The choice of particular methods of contraception and of hormone replacement therapy can reduce VTE risk.

- Because of the risk of bleeding, using anticoagulants for primary prevention of VTE is justified only in certain circumstances.

- Pregnancy is the only condition in which there is a guideline indication for thrombophilia testing, because test results in this setting can change recommendations for preventing VTE.

- Using a risk-stratification model is key to determining risk in both medically and surgically hospitalized patients. Trauma and major orthopedic surgery always place the patient at high risk of VTE. some benefit, broadly). There are, however, distinct behavioral characteristics and medical circumstances for which opportunities exist to reduce VTE risk-for example, when a person engages in long-distance travel, receives hormonal therapy, is pregnant, or has cancer. In each scenario, recognizing and mitigating risk are important.

\section{Statins offer a (slight) benefit}

There is evidence that statins reduce the risk of VTE-slightly ${ }^{20-23}$ :

- A large randomized, controlled trial showed that rosuvastatin, $20 \mathrm{mg} / \mathrm{d}$, reduced the rate of VTE, compared to placebo; however, the 2-year number needed to treat (NNT) was $349 .^{20}$ The VTE benefit is minimal, however, compared to primary prevention of cardiovascular disease with statins (5-year NNT $=56) .{ }^{21}$ The sole significant adverse event associated with statins was new-onset type 2 diabetes (5-year number needed to harm $=235){ }^{21}$

- A subsequent meta-analysis confirmed a small reduction in VTE risk with statins. ${ }^{22}$ In its 2012 guidelines, ACCP declined to issue a recom- mendation on the use of statins for VTE prevention. ${ }^{23}$ When considering statins for primary cardiovascular disease prevention, take the additional VTE prevention into account.

\section{Simple strategies can help prevent travel-related VTE}

Travel is a common inciting factor for VTE. A systematic review showed that VTE risk triples after travel of $\geq 4$ hours, increasing by $20 \%$ with each additional 2 hours. ${ }^{24}$ Most VTE occurs in travelers who have other VTE risk factors. ${ }^{25}$ Based on case-control studies, ${ }^{23}$ guidelines recommend these preventive measures:

- frequent calf exercises

- sitting in an aisle seat during air travel

- keeping hydrated.

A Cochrane review showed that graded compression stockings reduce asymptomatic DVT in travelers by a factor of 10 , in high- and low-risk patients. ${ }^{26}$

\section{VTE risk varies with type of hormonal contraception}

Most contraceptives increase VTE risk (TABLE $2^{27,28}$ ). Risk with combined oral contraceptives varies with the amount of estrogen and progesterone. To reduce VTE risk with oral contraceptives, patients can use an agent that contains a lower dose of estrogen or one in which levonorgestrel replaces other progesterones. $^{27}$

Studies suggest that the levonorgestrelreleasing intrauterine device and progestinonly pills are not associated with an increase in VTE risk. ${ }^{27}$ Although the quality of evidence varies, most nonoral hormonal contraceptives have been determined to carry a risk of VTE that is similar to that of combined oral contraceptives. ${ }^{28}$

\section{In hormone replacement,} avoid pills to lower risk

Hormone replacement therapy (HRT) for postmenopausal women increases VTE risk when administered in oral form, with combined estrogen and progestin HRT doubling the risk and estrogen-only formulations having a lower risk. ${ }^{29}$ VTE risk is highest in the first 6 months of HRT, declining to that of a 
TABLE 2

Contraceptive-related risk of venous thromboembolism ${ }^{27,28}$

\begin{tabular}{l|l}
\hline Method & RR $^{\mathrm{a}}$ \\
\hline $\begin{array}{l}\text { Combined oral contraceptives; } 30 \mathrm{mg} \text { of estrogen plus: } \\
\text { - drospirenone }\end{array}$ & 4 \\
$\bullet \quad$ levonorgestrel & 3.6 \\
\hline Progestin injection & 2 \\
\hline Transdermal contraceptive patches & 3.6 \\
\hline Levonorgestrel-releasing intrauterine device & 2.2 \\
\hline Progestin-only pills & 1 (no increase) \\
\hline Etonogestrel vaginal ring & 1 (no increase) \\
\hline Etonogestrel subcutaneous implant & Limited data ${ }^{\mathrm{b}}$ \\
\hline RR relative risk & Not studied
\end{tabular}

$\mathrm{RR}$, relative risk

a Compared to no contraception.

b Similar to that of oral contraceptives.

non-HRT user within 5 years. ${ }^{29}$ Neither transdermal HRT nor estrogen creams increase the risk of VTE, according to a systematic review. ${ }^{30}$ The estradiol-containing vaginal ring also does not confer increased risk. ${ }^{29}$

\section{Pregnancy, thrombophilia, and VTE prevention}

VTE affects as many as $0.2 \%$ of pregnancies but causes $9 \%$ of pregnancy-related deaths. ${ }^{18}$ The severity of VTE in pregnancy led the American College of Obstetricians and Gynecologists (ACOG) to recommend primary VTE prophylaxis in patients with certain thrombophilias. ${ }^{18}$ Thrombophilia testing is recommended in patients with proven high-risk thrombophilia in a first-degree relative. ${ }^{18}$ ACOG recognizes 5 thrombophilias considered to carry a high risk of VTE in pregnancy $^{18}$ :

- homozygous Factor V Leiden

- homozygous prothrombin G20210A mutation

- antithrombin deficiency

- heterozygous Factor V Leiden and prothrombin G20210A mutation

- antiphospholipid antibody syndrome.

ACOG recommends limiting thrombophilia testing to (1) any specific thrombophilia carried by a relative and (2) possibly, the antiphospholipid antibodies anticardiolipin and lupus anticoagulant. ${ }^{18,19}$ Antiphospho- lipid testing is recommended when there is a history of stillbirth, 3 early pregnancy losses, or delivery earlier than 34 weeks secondary to preeclampsia. $^{19}$

Primary VTE prophylaxis is recommended for pregnant patients with a high-risk thrombophilia; low-molecular-weight heparin (LMWH) is safe and its effects are predictable. ${ }^{18}$ Because postpartum risk of VTE is higher than antepartum risk, postpartum prophylaxis is also recommended with lowerrisk thrombophilias ${ }^{18}$; a vitamin $\mathrm{K}$ antagonist or LMWH can be used..$^{18}$ ACCP and ACOG recommendations for VTE prophylaxis in pregnancy differ slightly (TABLE $3^{16,18,19}$ ).

\section{Cancer increases risks of VTE and bleeding}

Cancer increases VTE risk $>6$-fold ${ }^{31}$; metastases, chemotherapy, and radiotherapy further increase risk. Cancer also greatly increases the risk of bleeding: Cancer patients with VTE have an annual major bleeding rate $\geq 20 \%{ }^{32}$ Guidelines do not recommend primary VTE prophylaxis for cancer, although American Society of Clinical Oncology guidelines discuss consideration of prophylaxis for select, highrisk patients, ${ }^{33,34}$ including those with multiple myeloma, metastatic gastrointestinal cancer, or metastatic brain cancer. ${ }^{31,34}$ Recent evidence (discussed in a moment) supports the use of apixaban for primary VTE prevention during chemotherapy for high-risk cancer. 
TABLE 3

Primary prevention of venous thromboembolism in pregnancy ${ }^{16,18,19}$

\begin{tabular}{|c|c|c|c|c|}
\hline \multirow[t]{2}{*}{ Clinical scenario } & \multicolumn{2}{|l|}{ ACOG recommendations } & \multicolumn{2}{|l|}{ ACCP recommendations } \\
\hline & $\begin{array}{l}\text { Antepartum } \\
\text { management }\end{array}$ & $\begin{array}{l}\text { Postpartum } \\
\text { management }\end{array}$ & $\begin{array}{l}\text { Antepartum } \\
\text { management }\end{array}$ & $\begin{array}{l}\text { Postpartum } \\
\text { Management }\end{array}$ \\
\hline Low-risk thrombophilia & Surveillance & $\begin{array}{l}\text { - Surveillance } \\
\text { - Consider } \\
\text { prophylactic LMWHa } \\
\text { daily for obesity, } \\
\text { immobility, or } \\
\text { cesarean delivery } \\
\end{array}$ & Surveillance & \\
\hline $\begin{array}{l}\text { Low-risk thrombophilia } \\
\text { with family history of } \\
\text { VTE }\end{array}$ & $\begin{array}{l}\text { - Surveillance } \\
\qquad \text { or } \\
\text { - Prophylactic LMWHa } \\
\text { daily }\end{array}$ & $\begin{array}{l}\text { - Prophylactic LMWHa } \\
\text { daily } \\
\qquad \text { or } \\
\text { - Prophylactic LMWHa } \\
\text { bid }\end{array}$ & Surveillance & $\begin{array}{l}\text { - Prophylactic LMWHa } \\
\text { daily or } \\
\text { - Prophylactic LMWH } \\
\text { bid } \\
\text { - or } \\
\text { - VKA }\end{array}$ \\
\hline $\begin{array}{l}\text { High-risk } \\
\text { thrombophiliab }^{b}\end{array}$ & \multicolumn{2}{|c|}{$\begin{array}{l}\text { - Prophylactic LMWHa daily } \\
\text { or } \\
\text { - Prophylactic LMWHa bid }\end{array}$} & $\begin{array}{l}\text { Surveillance (for } \\
\text { antiphospholipid } \\
\text { syndrome, add } \\
\text { prophylactic LMWH,a } \\
\text { daily or bid, plus low- } \\
\text { dose aspirin) }\end{array}$ & $\begin{array}{l}\text { - Prophylactic LMWHa } \\
\text { daily or } \\
\text { - Prophylactic LMWH } \\
\text { bid } \\
\text { - or } \\
\text { VKA }\end{array}$ \\
\hline $\begin{array}{l}\text { High-risk } \\
\text { thrombophilia with } \\
\text { family history of VTE }\end{array}$ & \multicolumn{2}{|c|}{$\begin{array}{r}\text { - Prophylactic LMWHa daily } \\
\text { or } \\
\text { - Prophylactic LMWHa bid } \\
\text { or } \\
\text { - Treatment-dose }{ }^{a} \text { LMWH }\end{array}$} & $\begin{array}{l}\text { - Prophylactic LMWHa } \\
\text { daily or } \\
\text { - Prophylactic LMWHa } \\
\text { bid } \\
\text { - Add low-dose aspirin } \\
\text { for antiphospholipid } \\
\text { syndrome }\end{array}$ & $\begin{array}{l}\text { - Prophylactic LMWHa } \\
\text { daily or } \\
\text { - Prophylactic LMWHa } \\
\text { bid } \\
\text { - or } \\
\text { VKA }\end{array}$ \\
\hline
\end{tabular}

ACCP, American College of Chest Physicians; ACOG, American College of Obstetricians and Gynecologists; LMWH, low-molecular-weight heparin; VKA, vitamin $\mathrm{K}$ antagonist; VTE, venous thromboembolism.

a Dosing

- Prophylactic LMWH: Equivalent to enoxaparin $40 \mathrm{mg}$ or dalteparin $5000 \mathrm{mg}$.

- Treatment-dose LMWH: Weight-based, equivalent to enoxaparin $1 \mathrm{mg} / \mathrm{kg}$ every 12 hours or dalteparin $200 \mathrm{U} / \mathrm{kg} / \mathrm{d}$.

${ }^{b}$ High-risk thrombophilias: homozygous Factor V Leiden, homozygous prothrombin G20210A mutation, antithrombin deficiency, heterozygous Factor V Leiden and prothrombin G20210A mutation, and antiphospholipid syndrome.

The Khorana Risk Score (TABLE $\mathbf{4}^{35,36}$ ) for VTE was developed and validated for use in patients with solid cancer ${ }^{35}$ : A score of 2 conveys nearly a $10 \%$ risk of VTE over 6 months. ${ }^{36}$ A recent study of 550 cancer patients with a Khorana score of $\geq 2$-the first evidence of risk-guided primary VTE prevention in cancer-showed that primary prophylaxis with $2.5 \mathrm{mg}$ of apixaban, bid, reduced the risk of
VTE (NNT = 17); however, the number needed to harm (for major bleeding) was $59 .{ }^{37}$ Mortality was not changed with apixaban treatment. ${ }^{37}$

\section{Primary VTE prevention in med-surg hospitalizations}

The risk of VTE increases significantly during hospitalization, although not enough to 
There is no prospective evidence that weight loss or control of diabetes or hypertension reduces the risk of VTE; smoking cessation does appear to reduce risk.

TABLE 4

\section{Khorana Risk Score for venous thromboembolism in patients with cancer ${ }^{35,36}$}

\begin{tabular}{l|l}
\hline Risk factor & Points ${ }^{\mathrm{a}}$ \\
\hline Cancer & 2 \\
\hline$\bullet$ Pancreas & 2 \\
\hline$\bullet$ Stomach & 1 \\
\hline$\bullet$ Bladder & 1 \\
\hline$\bullet$ Gynecologic & 1 \\
\hline$\bullet$ Lung & 1 \\
\hline$\bullet$ Lymphoma & 1 \\
\hline$\bullet$ Testicular & 0 \\
\hline$\bullet$ Other & 1 \\
\hline Body mass index $\geq 35$ & 1 \\
\hline Hemoglobin $<10 \mathrm{mg} / \mathrm{dL}$ (or using red blood cell growth factors) & 1 \\
\hline Platelet count $\geq 350 \times 103 / \mu \mathrm{L}^{\mathrm{b}}$ & 1 \\
\hline White blood cell count $>11 \times 103 / \mu \mathrm{L}^{\mathrm{b}}$ & \\
\hline
\end{tabular}

a Risk is high when the Khorana Risk Score is $\geq 2$ points. ${ }^{36}$

${ }^{b}$ Before chemotherapy.

Adapted from: Khorana et al. Blood. 2008. ${ }^{35}$

justify universal prophylaxis. Recommended prevention strategies for different classes of hospitalized patients are summarized below.

I In medically hospitalized patients, risk is stratified with a risk-assessment model. Medically hospitalized patients have, on average, a VTE risk of $1.2 \%^{23}$; 12 risk-assessment models designed to stratify risk were recently compared ${ }^{38}$ Two models, the Caprini Score (TABLE 5) ${ }^{39}$ and the IMPROVE VTE Risk Calculator ${ }^{40}$ were best able to identify low-risk patients (negative predictive value, $>99 \%$ ). ${ }^{38}$ American Society of Hematology guidelines recommend IMPROVE VTE or the Padua Prediction Score for risk stratification..$^{41}$ While the Caprini score only designates $11 \%$ of eventual VTE cases as low risk, both the IMPROVE VTE and Padua scores miss more than $35 \%$ of eventual VTE. ${ }^{38}$

Because LMWH prophylaxis has been shown to reduce VTE by $40 \%$ without increasing the risk of major bleeding, using Caprini should prevent 2 VTEs for every 1000 patients, without an increase in major bleeding and with 13 additional minor bleeding events. $^{42}$

I Critically ill patients are assumed to be at high risk of VTE and do not require stratification. ${ }^{23}$ For high-risk patients, prophylaxis with LMWH, low-dose unfractionated heparin (LDUH), or fondaparinux is recommended for the duration of admission. ${ }^{23}$ For patients at high risk of both VTE and bleeding, mechanical prophylaxis with intermittent pneumatic compression (IPC) is recommended instead of $\mathrm{LMWH}, \mathrm{LDUH}$, or fondaparinux. ${ }^{23}$

I Surgery, like trauma (see next page), increases the risk of VTE and has been well studied. Prophylaxis after orthopedic surgery differs from that of other types of surgery.

In orthopedic surgery, risk depends on the procedure. For major orthopedic surgery, including total hip or knee arthroplasty and hip fracture surgery, VTE prophylaxis is recommended for 35 days postsurgically. ${ }^{43}$ LMWH is the preferred agent, although many other means have been shown to be beneficial. ${ }^{44} \mathrm{~A}$ recent systematic review demonstrated that aspirin is not inferior to other medications after hip or knee arthroplasty. ${ }^{45}$ No mechanical or pharmacotherapeutic prophylaxis is generally recommended after nonmajor orthopedic surgery. ${ }^{43}$

Nonorthopedic surgery is stratified by risk factors, using Caprini ${ }^{44}$ (TABLE ${ }^{39}$ ). For 
TABLE 5

Caprini Risk Score for nonorthopedic surgery ${ }^{39}$

\begin{tabular}{|c|c|c|c|c|}
\hline Points & 1 & 2 & 3 & 5 \\
\hline $\begin{array}{l}\mathrm{F} \\
\mathrm{A} \\
\mathrm{C} \\
\mathrm{T} \\
\mathrm{O} \\
\mathrm{R} \\
\mathrm{S}\end{array}$ & $\begin{array}{l}\text { Age, } 41-60 \text { y } \\
\text { Minor surgery } \\
\text { Body mass index }>25 \\
\text { Swollen legs } \\
\text { Varicose veins } \\
\text { Pregnant or } \\
\text { postpartum } \\
\text { History of miscarriage } \\
\text { Oral contraception } \\
\text { Hormone replacement therapy } \\
\text { Sepsis } \leq 1 \text { mo previously } \\
\text { Serious lung disease } \leq 1 \text { mo } \\
\text { previously } \\
\text { Abnormal pulmonary function } \\
\text { History of acute myocardial } \\
\text { infarction } \\
\text { Congestive heart failure } \\
\text { History of inflammatory bowel } \\
\text { disease } \\
\text { Medical patient on bed rest }\end{array}$ & $\begin{array}{l}\text { Age, } 61-74 \text { y } \\
\text { Major open surgery } \\
>45 \text { min } \\
\text { Laparoscopic surgery } \\
>45 \text { min } \\
\text { Malignancy } \\
\text { Confined to bed } \\
>72 \mathrm{~h} \\
\text { Immobilizing cast } \\
\text { Central venous access }\end{array}$ & $\begin{array}{l}\text { Age, } \geq 75 \text { y } \\
\text { History of VTE } \\
\text { Family history of VTE } \\
\text { Factor V Leiden } \\
\text { Prothrombin } 20210 \mathrm{~A} \\
\text { mutation } \\
\text { Lupus anticoagulant } \\
\text { Anticardiolipin antibodies } \\
\text { Heparin-induced } \\
\text { thrombocytopenia } \\
\text { Other thrombophilia }\end{array}$ & $\begin{array}{l}\text { Stroke } \leq 1 \text { mo } \\
\text { previously } \\
\text { Hip, pelvis, or leg } \\
\text { fracture } \\
\text { Acute spinal cord } \\
\text { injury }\end{array}$ \\
\hline
\end{tabular}

Interpreting the Caprini Risk Score

\begin{tabular}{l|l|l}
\hline Score & Risk level & Recommended prophylaxis \\
\hline $0-1$ & Very low & None \\
\hline 2 & Low & IPC \\
\hline $3-4$ & Moderate & LMWH, LDUH, or IPC \\
\hline 25 & High & LMWH or LDUH, plus IPC \\
\hline
\end{tabular}

IPC, intermittent pneumatic compression; LDUH, low-dose unfractionated heparin; LMWH, low-molecular-weight heparin; VTE, venous thromboembolism.

Adapted from: Caprini. Dis Mon. 2005. ${ }^{39}$

medium-risk patients (Caprini score, 3-4) LDUH, LMWH, or IPC is recommended; for high-risk patients (Caprini score, $\geq 5$ ) preventive treatment should combine pharmacotherapeutic and mechanical prophylaxis. ${ }^{46}$ A recent meta-analysis, comprising 14,776 patients, showed that surgical patients with a Caprini score $\geq 7$ had a reduced incidence of VTE when given chemoprophylaxis, whereas patients whose score is $<7$ do not benefit from chemoprophylaxis. ${ }^{43}$ When bleeding risk is high, IPC is recommended as sole therapy. ${ }^{43}$ Prophylaxis is not recommended when risk (determined by the Caprini score) is low. ${ }^{46}$
I Post-hospitalization. Risk of VTE can persist for as long as 90 days after hospitalization; this finding has led to evaluation of the benefit of prolonged chemoprophylaxis. ${ }^{23}$ Extended-duration LMWH prophylaxis decreases the incidence of VTE, but at the cost of increased risk of major bleeding. ${ }^{47}$ Based on this evidence, guidelines recommend against prolonged-duration anticoagulation. ${ }^{23}$ A 2016 trial showed that 35 days of the direct-acting anticoagulant betrixaban reduced the risk of symptomatic VTE events, compared to 10 days of LMWH (NNT = 167), without increased risk of bleeding. ${ }^{48}$ This is a 
limited benefit, however, that is unlikely to change guideline recommendations.

\section{Trauma: VTE risk increases with severity}

Trauma increases the risk of VTE considerably. A national study showed that $1.5 \%$ of admitted trauma patients experienced VTE during hospitalization and that $1.2 \%$ were readmitted for VTE within 1 year. ${ }^{49}$ As many as $32 \%$ of trauma patients admitted to the intensive care unit experience VTE despite appropriate prophylaxis. ${ }^{50}$ A Cochrane Review ${ }^{51}$ found that:

- prophylaxis significantly reduces DVT risk

- pharmacotherapeutic prophylaxis is more effective than mechanical prophylaxis

Taking a statin can reduce the risk of VTEslightly.

Guidelines recommend that major trauma patients receive prophylaxis with LMWH, venous thromboembolism: a review. Open J Prev Med. 2012;2: 499-509.

13. Severinsen MT, Kristensen SR, Johnsen SP, et al. Smoking and venous thromboembolism: a Danish follow-up study. J Thromb Haemost. 2009;7:1297-1303.

14. Coppens M, Reijnders JH, Middeldorp S, et al. Testing for inherited thrombophilia does not reduce the recurrence of venous thrombosis. J Thromb Haemost. 2008;6:1474-1477.

15. Choosing Wisely. American Society of Hematology. Ten things physicians and patients should question. www.choosingwisely. org/societies/american-society-of-hematology/. Accessed September 28, 2020

16. Bates SM, Greer IA, Middeldorp S, et al. VTE, thrombophilia, antithrombotic therapy, and pregnancy: Antithrombotic Therapy and Prevention of Thrombosis, 9th ed: American College of Chest Physicians Evidence-Based Clinical Practice Guidelines. Chest. 2012;141(2 suppl):e691S-e736S.

17. Vossen CY, Conard J, Fontcuberta J, et al. Risk of a first venous thrombotic event in carriers of a familial thrombophilic defect. The European Prospective Cohort on Thrombophilia (EPCOT). J Thromb Haemost. 2005;3:459-464.

18. American College of Obstetricians and Gynecologists' Committee on Practice Bulletins-Obstetrics. ACOG Practice Bulletin No. 197: Inherited thrombophilias in pregnancy. Obstet Gynecol. 2018;132:e18-e34.

19. Committee on Practice Bulletins-Obstetrics, American College of Obstetricians and Gynecologists. Practice Bulletin No. 132: Antiphospholipid syndrome. Obstet Gynecol. 2012;120:1514-1521.

20. Glynn RJ, Danielson E, Fonseca FAH, et al. A randomized trial of rosuvastatin in the prevention of venous thromboembolism. NEngl J Med. 2009;360:1851-1861.

21. Taylor F, Huffman MD, Macedo AF, et al. Statins for the primary prevention of cardiovascular disease. Cochrane Database Syst Rev. 2013(1):CD004816 LDUH, or IPC. ${ }^{46}$ JFP

\section{CORRESPONDENCE}

Michael J. Arnold, MD, CDR, MC, USN; Uniformed Services University of the Health Sciences, 4301 Jones Bridge Road, Jacksonville, FL 32214; michael.arnold@usuhs.edu.

\section{References}

1. Beckman MG, Hooper WC, Critchley SE, et al. Venous thromboembolism: a public health concern. Am J Prev Med. 2010. 38 (4 suppl):S495-S501.

2. Tagalakis V, Patenaude V, Kahn SR, et al. Incidence of and mortality from venous thromboembolism in a real-world population: the Q-VTE Study Cohort. Am J Med. 2013;126:832.e13-e21.

3. Yeh RW, Sidney S, Chandra M, et al. Population trends in the incidence and outcomes of acute myocardial infarction. $N$ Engl J Med. 2010. 362:2155-2165.

4. Cushman M, Tsai AW, White RH, et al. Deep vein thrombosis and pulmonary embolism in two cohorts: the longitudinal investigation of thromboembolism etiology. Am J Med. 2004;117:19-25.

5. Goldhaber SZ. Venous thromboembolism: epidemiology and magnitude of the problem. Best Pract Res Clin Haematol. 2012;25:235-242

6. Stone J, Hangge P, Albadawi $\mathrm{H}$, et al. Deep vein thrombosis: pathogenesis, diagnosis, and medical management. Cardiovasc Diagn Ther. 2017;7(suppl 3):S276-S284.

7. Olaf M, Cooney R. Deep venous thrombosis. Emerg Med Clin North Am. 2017;35:743-770.

8. Sajid MS, Ahmed N, Desai M, et al. Upper limb deep vein thrombosis: a literature review to streamline the protocol for management. Acta Haematol. 2007;118:10-18.

9. Bates SM, Ginsberg JS. Clinical practice. Treatment of deep-vein thrombosis. NEngl J Med. 2004;351:268-277.

10. Chandra D, Parisini E, Mozaffarian D. Meta-analysis: travel and risk for venous thromboembolism. Ann Intern Med. 2009;151:180-190

11. Goldhaber SZ. Risk factors for venous thromboembolism. J Am Col Cardiol. 2010;56:1-7.

12. Yang G, De Staercke C, Hooper WC. The effects of obesity on
2. Squizzato A, Galli M, Romualdi E, et al. Statins, fibrates, and venous thromboembolism: a meta-analysis. Eur Heart $J$. 2010;31:1248-1256.

23. Kahn SR, Lim W, Dunn AS, et al. Prevention of VTE in nonsurgical patients: Antithrombotic Therapy and Prevention of Thrombosis, 9th ed: American College of Chest Physicians EvidenceBased Clinical Practice Guidelines. Chest. 2012;141(2 suppl): e195S-e226S.

24. Kelman CW, Kortt MA, Becker NG, et al. Deep vein thrombosis and air travel: record linkage study. BMJ. 2003;327:1072.

25. Johnston RV, Hudson MF; Aerospace Medical Association Air Transport Medicine Committee. Travelers' thrombosis. Aviat Space Environ Med. 2014;85:191-194.

26. Clarke MJ, Broderick C, Hopewell S, et al. Compression stockings for preventing deep vein thrombosis in airline passengers. Cochrane Database Syst Rev. 2016;9:CD004002.

27. van Hylckama Vlieg A, Middledorp S. Hormone therapies and venous thromboembolism: where are we now? J Thromb Haemost 2011;9:257-266.

28. Tepper NK, Dragoman MV, Gaffield ME, et al. Nonoral combined hormonal contraceptives and thromboembolism: a systematic review. Contraception. 2017;95:130-139.

29. Lekovic D, Miljic P, Dmitrovic A, et al. How do you decide on hormone replacement therapy in women with risk of venous thromboembolism? Blood Rev. 2017;31:151-157.

30. Rovinski D, Ramos RB, Fighera TM, et al. Risk of venous thromboembolism events in postmenopausal women using oral versus non-oral hormone therapy: a systematic review and meta-analysis. Thromb Res. 2018;168:83-95.

31. Horsted F, West J, Grainge MJ. Risk of venous thromboembolism in patients with cancer: a systematic review and meta-analysis. PLoS Med. 2012;9:e1001275. during anticoagulant treatment in patients with cancer. Thromb Res. 2014;133(suppl 2):S49-S55.

33. Kearon C, Akl EA, Ornelas J, et al. Antithrombotic therapy for VTE disease: CHEST Guideline and Expert Panel Report. Chest. 2016;149:315-352.

34. Lyman GH, Khorana AA, Kuderer NM, et al. Venous thromboembolism prophylaxis and treatment in patients with cancer: American Society of Clinical Oncology Clinical Practice Guideline update. J Clin Oncol. 2013;31:2189-2204.

35. Khorana AA, Kuderer NM, Culakova E, et al. Development and validation of a predictive model for chemotherapy-associated thrombosis. Blood. 2008;111:4902-4907.
32. Kamphuisen PW, Beyer-Westendorf J. Bleeding complications 
36. Ay C, Dunkler D, Marosi C, et al. Prediction of venous thromboembolism in cancer patients. Blood. 2010;116:5377-5382.

37. Carrier M, Abou-Nassar K, Mallick R, et al; AVERT Investigators. Apixaban to prevent venous thromboembolism in patients with cancer. N Engl J Med. 2019;380:711-719.

38. Cobben MRR, Nemeth B, Lijfering WM, et al. Validation of risk assessment models for venous thrombosis in hospitalized medical patients. Res Pract Thromb Haemost. 2019;3:217-225.

39. Caprini JA. Thrombosis risk assessment as a guide to quality patient care. Dis Mon. 2005;51:70-78.

40. Spyropoulos AC, Anderson FA Jr, FitzGerald G, et al; IMPROVE Investigators. Predictive and associative models to identify hospitalized medical patients at risk for VTE. Chest. 2011;140:706-714.

41. Kanaan AO, Silva MA, Donovan JL, et al. Meta-analysis of venous thromboembolism prophylaxis in medically Ill patients. Clin Ther. 2007;29:2395-2405.

42. Schünemann $\mathrm{HJ}$, Cushman $\mathrm{M}$, Burnett $\mathrm{AE}$, et al. American Society of Hematology 2018 guidelines for management of venous thromboembolism: prophylaxis for hospitalized and nonhospitalized medical patients. Blood Adv. 2018;2:3198-3225.

43. Falck-Ytter Y, Francis CW, Johanson NA, et al. Prevention of VTE in orthopedic surgery patients: Antithrombotic Therapy and Prevention of Thrombosis, 9th ed: American College of Chest Physicians Evidence-Based Clinical Practice Guidelines. Chest. 2012;141(2 suppl):e278S-e325S

44. Pannucci CJ, Swistun L, MacDonald JK, et al. Individualized venous thromboembolism risk stratification using the 2005 Caprin Score to identify the benefits and harms of chemoprophylaxis in surgical patients: a meta-analysis. Ann Surg. 2017;265:1094-1103.

45. Matharu GS, Kunutsor SK, Judge A, et al. Clinical effectiveness and safety of aspirin for venous thromboembolism prophylaxis after total hip and knee replacement: a systematic review and meta-analysis of randomized clinical trials. JAMA Intern Med. 2020;180:376-384.

46. Gould MK, Garcia DA, Wren SM, et al. Prevention of VTE in nonorthopedic surgical patients: Antithrombotic Therapy an Prevention of Thrombosis, 9th ed: American College of Ches Physicians Evidence-Based Clinical Practice Guidelines. Chest 2012;141(2 suppl):e227S-e277S.

47. Hull RD, Schellong SM, Tapson VF, et al. Extended-duration venous thromboembolism prophylaxis in acutely ill medical patients with recent reduced mobility: a randomized trial. Ann Intern Med. 2010;153:8-18.

48. Cohen AT, Harrington RA, Goldhaber SZ, et al. Extended throm boprophylaxis with betrixaban in acutely ill medical patients. NEngl J Med. 2016;375:534-544.

49. Rattan R, Parreco J, Eidelson SA, et al. Hidden burden of venous thromboembolism after trauma: a national analysis. I Trauma Acute Care Surg. 2018;85:899-906.

50. Yumoto T, Naito H, Yamakawa Y, et al. Venous thromboembolism in major trauma patients: a single-center retrospective cohort study of the epidemiology and utility of D-dimer for screening. Acute Med Surg. 2017;4:394-400.

51. Barrera LM, Perel P, Ker K, et al. Thromboprophylaxis for trauma patients. Cochrane Database Syst Rev. 2013(3):CD008303.

\section{WE WANT TO HEAR FROM YOU!}

Have a comment on an article, editorial, or department? You can send it by:

1. E-MAIL:jfp.eic@gmail.com

2. FAX: 973-206-9251 or

3. MAIL: The Journal of Family Practice,

7 Century Drive, Suite 302, Parsippany,

NJ 07054

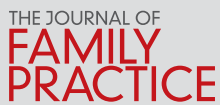

LETTERS SHOULD BE 200 WORDS OR LESS. THEY WILL BE EDITED PRIOR TO PUBLICATION.

\section{$\oslash$ Visit us $₫$ mdedge.com/familymedicine}

\section{(1)) Study offers reassurance to postmenopausal women taking hormone therapy}

Doug Campos-Outcalt, MD, MPA

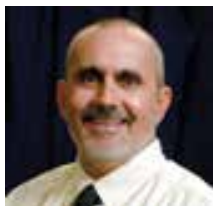

\section{ONLINE EXCLUSIVES}

- Low back pain in youth: Recognizing red flags

- PHOTO ROUNDS Rapidly developing vesicular eruption

- CLINICAL INQUIRIES Does early introduction of peanuts to an infant's diet reduce the risk for peanut allergy?

- RESIDENTS' RAPID REVIEW A 5-question monthly quiz to help you prepare for the family medicine certification exam. This month: Pediatric emergencies

\section{ONLINE AHEAD OF PRINT}

Systemic racism and health disparities: A statement from editors of family medicine journals

\section{PHOTO ROUNDS FRIDAY}

Test your diagnostic skills at www.mdedge.com/ familymedicine/photo-rounds

\section{PLUS}

Today's headlines in family medicine

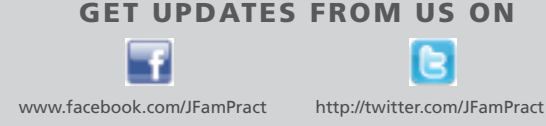

www.mdedge.com/familymedicine 